\title{
INFLUENCE OF ENERGY-YIELDING NUTRIENTS IN SUMMER AND WINTER FEED RATIONS ON THE LEVELS OF NON-ESTERIFIED FATTY ACIDS IN THE BLOOD PLASMA OF COWS IN VARIOUS LACTATION PHASES
}

\author{
M. LEBEDA, J. PR̆IKRYLOVÁ
} Department of Diagnostics, Therapy and Prevention of Animal Diseases, University of Veterinary
Science, 61242 Brno

Received February 8, 1980

\begin{abstract}
Lebeda M., Přikrylová J.: Influence of Energy-yielding Nutrients in Summer and Winter Feed Rations on the Levels of Non-esterified Fatty Acids in the Blood Plasma of Cows in Various Lactation Phases. Acta vet. Brno, 50, 1981: 179-189.

The NEFA concentration in the blood plasma of 552 cows held at large-scale production units was determined and the degree of requirement coverage of digestible nitrogen substances (DNS) and of energy (starch equivalent SE) and their ratio according to the Czechoslovak Standard CSN 467070 was found. Ten feed rations and 178 cows were included into the period of green food, 21 feed rations and 374 cows in the winter feeding period. The sets of 18 cows were divided into groups containing six animals each and were examined: 1 . in the $1 \mathrm{st}-2$ nd month of lactation, 2. in the 4th-6th month of lactation and 3. in the 8th-9.5 month of pregnancy, in the dry period.

The NEFA concentrations in the whole cow population were found to be significantly $(P<0.01)$ higher if summer feed rations were used $\left(0.165 \mathrm{mmol} .1^{-1} \pm\right.$ \pm 0.138 ) with a marked average surplus of DNS and SE when compared with winter feed rations $\left(0.131 \mathrm{mmol} .1^{-1} \pm 0.153\right)$ with a mild average deficiency of DNS and small surplus of SE. The difference of summer and winter NEFA levels in the whole cow population is caused first of all by significantly $(P<0.001)$ higher NEFA values in cows in the first lactation phase $\left(0.23 \mathrm{mmol} .1^{-1} \pm 0.19\right.$ in summer; $0.145 \mathrm{mmol} .1^{-1} \pm 0.161$ in winter) which have in average a slight DNS deficiency and higher SE deficiency in summer and higher deficit of DNS and SE within the level of the standard in winter. The NEFA concentrations of cows in the first lactation phase and of late-pregnant cows $\left(0.168 \mathrm{mmol} .1^{-1} \pm 0.142\right.$ in summer; $0.145 \mathrm{mmol} .1^{-1} \pm 0.1428$ in winter) were found to be both in summer and winter significantly $(P<0.001)$ higher than of those in the second lactation phase $\left(0.086 \mathrm{mmol} .1^{-1} \pm 0.0767\right.$ in summer $0.078 \mathrm{mmol} .1^{-1} \pm 0.0635$ in winter $)$. The NEFA concentration of cows in the first lactation phase and late-pregnant cows was found to differ significantly neither in summer nor in winter although there is a substantial difference in the coverage of energy nutrient requirement.

The reasons of different NEFA concentrations in individual phases of a reproduction cycle from the point of view of found saturation of energy nutrient requirements and of the influence of other factors, the applicability of plasma NEFA determination as an indicator of adequacy of cow nutrition have been discussed.
\end{abstract}

Cows, digestible nitrogen substances, starch equivalent, calorie-protein ratio, plasma $N E F A$, first and second lactation phases, late pregnancy.

Non-esterified fatty acids (NEFA) present in blood plasma are loosely bound to albumin. They are released from this bond during oxidation or during the reserve deposition, the source of NEFA being the hydrolysis of triglycerides from food. This takes partly place in the intestine and to a greater extent in liver. Another source of NEFA is seen in the hydrolysis of triglycerides present 
in form of fat reserves (Campbell et al. 1965). The NEFA release from the deposited fat tissue is stimulated by the growth hormone, adrenocorticotrophic hormone as well as by adrenalin (Kolb and Gürtler 1971). The neutral fat in fat tissue originates either from fats or from carbohydrates obtained in food (W right 1967). A close relationship exists between these two nutrients, in which the rate of fat or carbohydrate degradation is determined by entering rate of these substances into the intermediary metabolism and by the energy requirement (Kolb and Gürtler 1971). Fatty acids function in the intermediary metabolism as a highly efficient source of energy, the yield reported e. g. for palmitic acid being 129 mole of ATP. This value corresponds to $1032 \mathrm{kcal}$, i. e. to $45 \%$ of energy yield (Bergner 1971). In the case of stearic acid the value was found to be 146 mole of ATP (Kolb and Gürtler 1971). The gluconeogenic portion of fat component (glycerol) in fed ruminants is about $5-15 \%$ and increases to $25-45 \%$ after $2-3$ days of starvation (Bergman 1976).

Calving and the onset of lactation cause great variations in metabolism of high-producing dairy cows (Radlof 1966; Pehrson 1971; Rémond 1973). Efficient dairy cows get usually into the negative energetic balance during the first weeks of lactation and have to mobilize their fat reserves. The utilization of body fat reserves is characterized by higher concentrations of NEFA in plasma (Brumby 1975, quot. Dale, Vik-Mo and Fjellheim 1979; Espinasse and Ruckebush 1976; Parker 1976) while during reserve storing the NEFA concentrations are lower (Holmes and Lambourne 1970). The practical application of NEFA levels in the blood plasma as the indicator of the energy intake adequacy has, however, been questioned on the basis of homeostatic mechanisms (Rook and Line 1961), the variability of their relationships (Fisher et al. 1975) and also on the basis of short-term daily fluctuations in NEFA which decrease after feeding and increase with fattening and with mild excitement (Holmes and Lambourne 1970). Parker and Blowey (1976) have drawn the attention to the fact that every blood component fluctuating significantly in short intervals is difficult to interpret in terms of nutrition.

In order to assess the relevance of objections as to the practical application of plasma NEFA levels as the indicator of body fat mobilization in dairy cows and their energy balance in lactation, we have followed the NEFA levels in cows in various stages of lactation with known winter and summer feed rations at large-scale production units.

\section{Materials and Methods}

During the first eight months of 1979,374 cows fed on winter feed rations at 21 farms and 178 cows given summer feed rations at 10 farms were examined. In each set approximately one third of cows was in the first lactation phase, i. e. up to two months after calving, one third of cows in the second lactation phase, i. e. 4-6 months after calving, sired and in most cases pregnant, and one third of cows in the late stage of pregnancy, i. e. in the 8-9.5th month of pregnancy and in the dry period. In all cases the supplementation with energy-yielding nutrients, i. e. starch equivalent and digestible nitrogen substances (DNS) for both groups of production cows and the group of late-pregnant cows was calculated on the basis of laboratory food analyses or mean district values or table values. This value was compared with the Czechoslovak Standard No. 467070 for farm animal nutrient requirements. The mean level of supplementation with energy-yielding nutrients and their ratio for the whole sets of dairy cows given summer and winter feed rations and for individual groups of cows according to the lactation phase with both types of feed rations was also calculated. As for breeds, $48.4 \%$ of cows were of Bohemian Spotted, $38.7 \%$ of Black Spotted Lowland breed and its cross-breds and $12.9 \%$ of Danish Red breed.

Samples of venous blood were taken between 9.30 and $11.30 \mathrm{a}$. m. and were treated with heparin. The NEFA level was determined using the Boehringer colorimetric test, the error of measurement being $8 \%$.

The frequency of NEFA values when green food was given and when winter feed rations were used, was determined and mean values, medians, standard deviations and the difference significance were evaluated using the large sampling test and t-test (Homolka 1956). The same operations were carried out in groups of cows classified according to lactation phase and in both feeding periods; the statistical significance of differences between individual cow groups with the same basic type of feed ration and the significance of differences between the same cow groups with summer and winter rations were also evaluated. The values found were estimated with regard to the level of energy-yielding nutrient coverage. 


\section{Results}

The characteristics of feed rations from the view of energy-yielding nutrient coverage during the period of NEFA level following is summarized in Table 1. It follows from the table that in the case of summer feed rations taken from whole sets of dairy cows the surplus of DNS was higher while the surplus of energy was lower which is confirmed also by a relatively high percentage of feed rations with a narrowed calorie-protein ratio. The average nutrient surplus was caused first of all by overfeeding of cows in the second lactation phase (II) and mostly of late-pregnant cows, in the dry period (III). In these two groups the proportion

Table 1

Deficiency or surplus of energy nutrients and the calorie-protein ratio in feed rations of cows in the summer and winter periods in the average of the whole population of cows and in individual groups of cows according to the lactation phase and with regard to the Czechoslovak standard CSN 467070

DNS given in grams/animal/day, SE analogically in kg

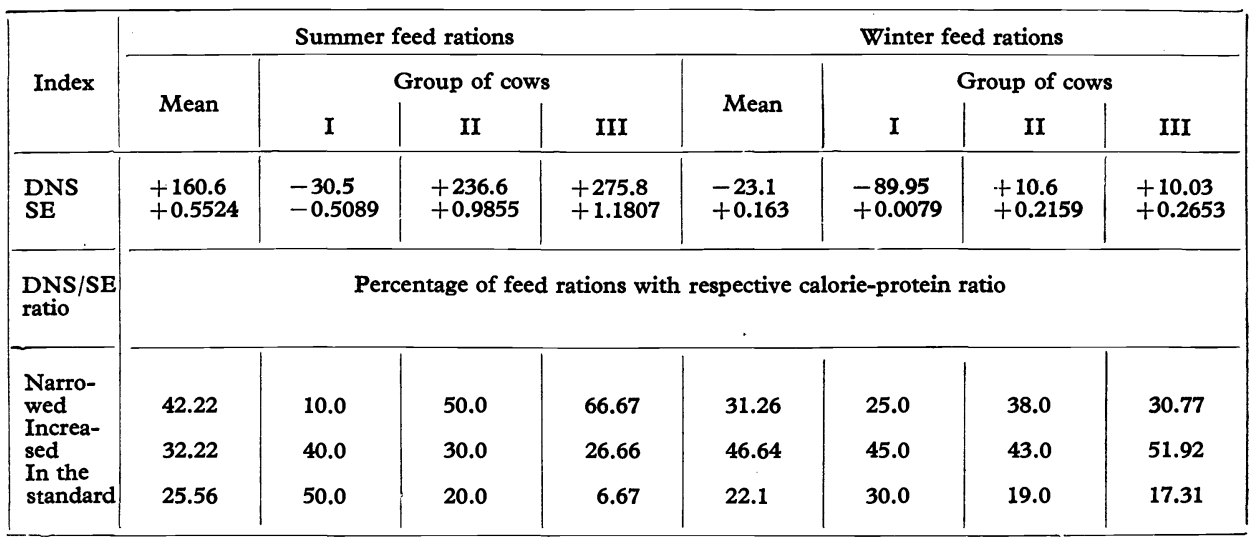

of feed rations with a narrowed calorie-protein ratio also increases to 50 and $66.7 \%$, the proportion of feed rations with their calorie-protein ratio in the standard proportionally decreasing (to 20 and $6.7 \%$ ). The part of feed rations with increased calorie-protein ratio was 30 and $26.7 \%$ in these groups. The overfeeding in these two cow groups was first of all brought about by large basal rations of green food (alfalfa, clover, maize) and by undifferentiated nutrition of late-pregnant cows. The nutrition of cows in the first phase (I), i. e. in the period of the highest milk production, differs significantly from preceding groups above all by the energy deficit and DNS deficit when $50 \%$ of feed rations has standardized calorie-protein ratio, $40 \%$ increased calorie-protein ratio and $10 \%$ narrowed calorie-protein ratio. This condition was effected by the supplement of the DOG mixture which is a typical carbohydrate rich feed (the calorie-protein ratio 8.26) in doses not fully covering the energy requirement.

The coverage of energy-yielding nutrient demand in winter feed rations was found to be satisfactory in average with a slight shortage of DNS and mild surplus of energy, the proportion of feed rations with increased calorie-protein ratio being relatively the highest, that with decreased ratio lower and that with ratio in standard being the lowest. The coverage of energy-yielding nutrients in groups of cows in the second lactation phase and in late-pregnant cows was also 
satisfactory, the energy surplus being mild. This surplus of energy was found to be higher in some farms $(43 \%$ and $51.1 \%$ of feed rations with an increased calorie-protein ratio). On other farms the absolute or relative DNS surplus produced a decreased calorie-protein ratio (II $-38 \%$, III $-30.8 \%$ of feed rations). The calorie-protein ratio in the standard was, however, represented by 19 and $17.3 \%$ only. The feed rations of cows in the first lactation phase were characterized first of all by a satisfactory coverage of energy requirement with a marked shortage of DNS which was typical of most farms. For this reason $45 \%$ of feed rations had the increased calorie-protein ratio, $30 \%$ in the standard and only $25 \%$ was with the decreased calorie-protein ratio.

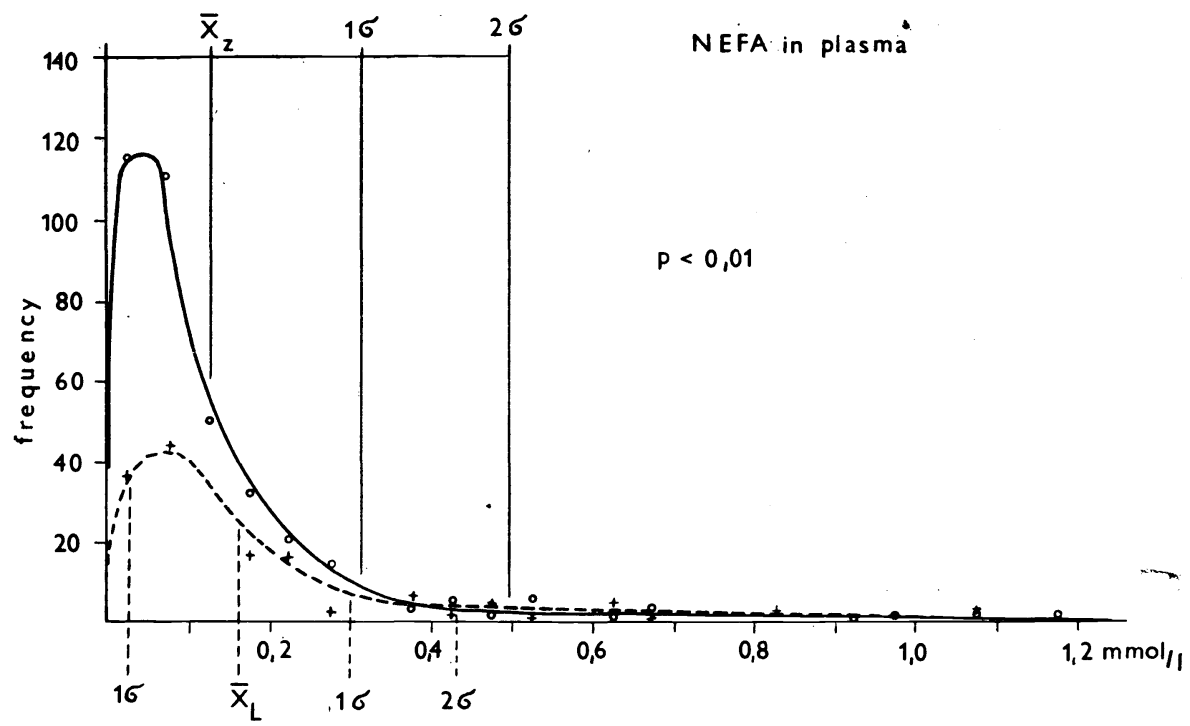

Fig. 1. Frequency and distribution curves of NEFA values found in the blood plasma of cows fed winter feed rations (open symbols, solid line) and summer feed rations (daggers, dashed line). Mean value $(\bar{x})$ and standard deviation $(\sigma)$ of summer values $(L)$ are plotted on the lower axis $X$, winter values $(Z)$ on the upper axis $X$ with a corresponding index $(L$ or $Z$ ). NEFA values are given in mmol $.1^{-1}$ on the lower $X$ axis. The significance of difference between summer and winter values is in the right part of the diagram. Both curves exhibit the Poisson-Charlier type of distribution.

The values of NEFA concentrations found in blood plasma of the whole sets of cows regardless of the lactation phase with green and winter feeding (Fig. 1 and Table 2) differ significantly $(P<0.01)$. The average value $0.165 \pm 0.138 \mathrm{mmol}$. $.1^{-1}$ of NEFA when green food was used was found to be significantly higher than that for the winter feeding $\left(0.131 \pm 0.153 \mathrm{mmol}^{-1} \mathrm{1}^{-1}\right)$, the influence of feed ration level on both feeding periods being, therefore, evident. Median was cal-

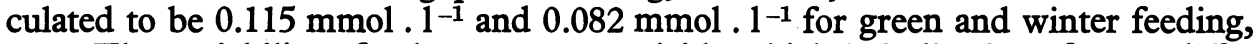
resp. The variability of values was appreciable which is indicative of great differences in the coverage of energy nutrient demand as well.

The values of NEFA concentration in plasma of cows grouped according to lactation phase are given in the Fig. 2 and Table 2. It follows from the diagram and statistical evaluation that the NEFA level in whole sets of cows with green and winter feeding was brought about first of all by the differing concentration 
Table 2

The medians of NEFA concentration in the blood plasma of cows in mmol . 1-1

\begin{tabular}{|l|c|c|}
\hline & Summer feed rations & Winter feed rations \\
\hline Mean of the population & 0.115 & 0.082 \\
Group I & 0.171 & 0.090 \\
Group II & 0.070 & 0.057 \\
Group III & 0.122 & 0.095 \\
\hline
\end{tabular}

of NEFA in cows in the first phase of lactation. The average level of this group was found to be significantly $(P<0.01)$ higher $\left.\left(0.230 \pm 0.190 \mathrm{mmol}^{-1}\right)^{-1}\right)$ with summer type of feeding when the energy shortage is pronounced in comparison to the winter type of feeding $\left(0.145 \pm 0.161 \mathrm{mmol}^{-1} \mathrm{1}^{-1}\right)$ where the energy requirement is covered. Summer and winter values of cows in the second phase of lactation $\left(0.086 \pm 0.7067\right.$ and $0.078 \pm 0.635 \mathrm{mmol}^{-1}$, resp.) and also of

Fig. 2. The medium concentration and the standard deviation of plasma NEFA of cows in the first phase of lactation (I), in the second lactation phase (II) and late pregnant cows in the dry period (III) given winter (index $Z$ ) and summer (index $L$ ) feed rations. The NEFA concentration in $\mathrm{mmol} .1^{-1}$ at the $Y$ axis. The significance of differences between summer and winter values are marked in the diagram, the significance of intergroup difference with the same type of feeding is presented in the column in the right part of the diagram.

$$
\begin{aligned}
& P< \\
& \mathrm{I}_{\mathrm{w}} \mathrm{II}_{\mathrm{w}} 0,001 \\
& \text { I }_{\mathrm{w}} \text { III }_{\mathrm{w}} \text { N. S. } \\
& \text { II }_{\mathrm{w}} \text { III }_{\mathrm{w}} 0,001 \\
& \text { I }_{\mathrm{S}} \mathrm{II}_{\mathrm{S}} 0,001 \\
& \text { I }_{\mathbf{S}} \text { III }_{\mathbf{S}} \text { N. S. } \\
& \text { II }_{\text {s }} \text { III }_{s} 0,001
\end{aligned}
$$

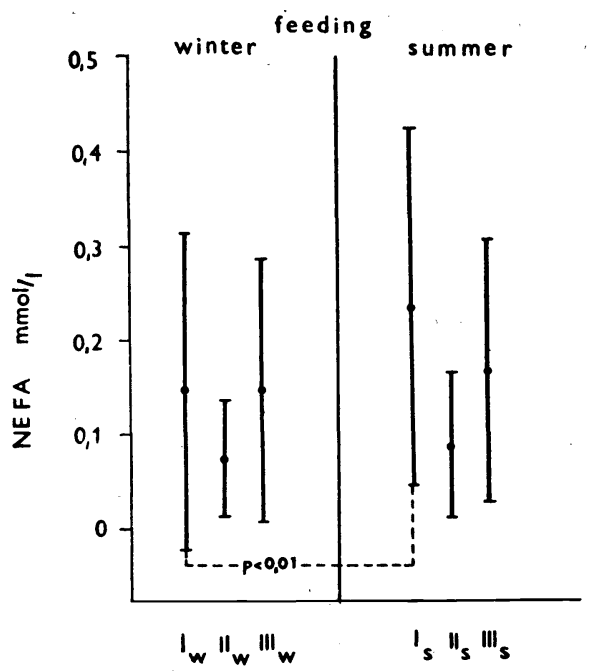

late-pregnant cows $\left(0.168 \pm 0.142\right.$ and $0.145 \pm 0.1428 \mathrm{mmol} .1^{-1}$, resp.) do not differ significantly, this being in accordance with the energy surplus in both groups with both types of feeding. During summer feeding the NEFA concentrations in plasma of cows in the first lactation phase are significantly higher $(P<0.001)$ than in the second lactation phase, corresponding to the energy shortage in group I cows and to energy surplus in group II cows. Significantly higher NEFA levels were found in late-pregnant cows $\left(0.168 \pm 0.142 \mathrm{mmol}^{1-1}\right)$ when compared with cows in the second lactation phase although the average coverage of energy requirement is slightly higher in the former. The NEFA levels of cows in the first lactation phase and of late-pregnant cows do not differ significantly, $0.23 \pm 0.19$ and $0.168 \pm 0.142 \mathrm{mmol}^{-1} \mathrm{l}^{-1}$, resp., although there is a large difference in energy requirement coverage between them.

In the time of winter feed rations the cows in the first lactation phase were found to have also significantly $(P<0.001)$ higher values of plasma NEFA 
as compared with cows in the second lactation phase $\left(0.145 \pm 0.161 \mathrm{mmol} .1^{-1}\right.$ and $0.078 \pm 0.0635 \mathrm{mmol}^{1-1}$, resp.), the latter having a pronounced energy surplus. The significant difference $(P<0.001)$ in NEFA values was also observed between cows in the second lactation phase and late-pregnant cows, the values of the latter being $0.145 \pm 0.1428 \mathrm{mmol} .1^{-1}$. Similarly as with summer feed rations the winter levels of plasma NEFA do not significantly differ in the first lactation phase and late pregnancy, the means being identical and scatter higher in the first lactation phase.

\section{Discussion}

It follows from the different composition of summer and winter feed rations that the degree and coverage of energy-yielding nutrient demand significantly influence the NEFA level in blood plasma. The NEFA levels increase with summer feed rations both in the whole cow population and in individual groups where the difference is significant in cows in the first lactation phase only.

From the data found it follows that the low input of energy in cows in the first lactation phase (I) and with summer feed rations significantly increases the NEFA level in their blood plasma when compared with groups of cows whose energy input is covered in surplus (group II and III) and even if compared with the group I in winter period when their energy coverage is within the standard. The NEFA level as an index of adequacy of energy coverage in a feed ration does not appear to be a simple criterion in groups II and III, both between the two groups and in comparison of NEFA values in winter and summer feed rations from the view of energy demand coverage. If the level of energy requirement coverage fundamentally influences the release of fat from adipose tissue or its deposition then the NEFA concentrations in these groups of cows should be higher in winter season when the energy surplus is in average lower than in summer season. The NEFA levels are in fact insignificantly lower in winter period. A similar, but significant, disproportion also exists between groups II and III. Although the late-pregnant cow group (III) has higher energy surplus both in summer and winter than the group in the second lactation phase (II), significantly higher plasma NEFA levels were found in the former. The NEFA levels do not significantly differ among cows in the first lactation phase and late-pregnant cows either in summer or in winter although there is a substantial difference between them as far as the energy requirement coverage during summer feeding rations and during winter feeding rations is concerned. These discrepancies cannot be explained as an effect of short-termed fluctuations of NEFA after feeding and by excitement as suggested Holmes and Lambourne (1970) quot. Parker and Blowey (1976) since the conditions were the same in all cow groups at the time of sampling. The explanation can rather be sought in the effect of different intake of DNS and energy, in the calorie-protein ratio in summer and winter feeding rations of individual groups of cows and in different hormonal activity of pregnant cows.

The groups II and III were markedly overfed by DNS in summer period, the DNS participating in the surplus of starch value in the feed ration in average by $22.6 \%$ and $22 \%$ in groups II and III, resp. The specific dynamic effect of protein on basal metabolism which can be raised by this way by 20 and more per cent (Wright 1967) is generally known. The decreased calorie-protein ratio was found to predominate over the increased and normal ones in cows of the groups II and III, the most expressive being in late-pregnant cows (see Table 1). 
The feed rations of these two groups of cows grossly differ from that of cows in the first phase of lactation where the lowered calorie-protein ratio represented $10 \%$ of feed rations only. Further increase of basal imetabolism in late-pregnant cows, largely in the last stage of pregnancy, is due to the increasing metabolism of the foetus (Stojanovský 1959 - quot. Boda 1969). This effect is then enhanced, in the case of pregnant cows, by the influence of the growth hormone and ACTH stimulating lipolysis of adipose tissue; fatty infiltration of liver, ketosis, negative nitrogen balance etc. then occur (Holub 1969; Campbell, Dickinson, Slater 1965). This explanation is further supported by our observation of singificantly higher levels of ammonia in urine and of urea levels in the blood of late-pregnant cows which raises suspicion of liver damage (Lebeda, Přikrylová and Buš 1980). Other hormonal effects can, nevertheless, be involved (Luthman and Johnson 1972b).

It is further necessary to take into consideration that in the group of late-pregnant cows there are animals $8-9.5$ months pregnant. The nutritional requirements increase during last months of pregnancy and cows 8 months pregnant are on the contrary often overfed. For example from the examined set of cows eight months pregnant not even one feed ration in the summer period had a standard calorie-protein ratio, $70 \%$ and $30 \%$ of rations having this ratio decreased and increased, resp. As far as the winter period is concerned a standard calorie-protein ratio was found in $25 \%$, decreased in $30 \%$ and increased in $45 \%$ of feed rations.

It can be assumed that even a marked shortage of DNS can increase the NEFA level in plasma, both with subnormal and normal coverage of energy requirement, due to the increased proportion of lipolysis on gluconeogenesis (Bergman 1973; Brockman et al. 1975).

No literature data are known to us concerning the influence of feed rations based on green and preserved food on the NEFA levels in cow blood plasma and NEFA levels in late-pregnant cows. Most workers dealing with NEFA have been directed either to values of healthy and diseased animals (Bergman 1971 quot. Sarabrin et al. 1972; Luthman and Johnson 1972a; Kronfeld 1965) or to values in various lactation phases and in the period of service (Dale, Vik-Mo, Fjellheim 1979; Parker and Blowey 1976) and to the influence of energy intake in the first two phases of lactation (Parker 1976). Comparing the data presented in the mentioned literature with the data obtained by us, our NEFA values in the whole cow population both in summer and winter feed rations are lower than the values given by Luthman and Johnson (1972a) $(0.280 \pm$ $\left.\pm 0.08 \mathrm{mmol} 1^{-1}\right)$, Bergman (1971) $\left(0.300 \mathrm{mmol} .1^{-1}\right)$ or Kronfeld (1965) $\left(0.286 \pm 0.146 \mathrm{mmol} .1^{-1}\right)$ in healthy cows. The standard deviations found by us $\left(0.138 \mathrm{mmol} .1^{-1}\right.$ and $0.153 \mathrm{mmol} .1^{-1}$ in summer and winter, resp.) are, however, very similar to those established by Kronfeld. The NEFA concentrations found in cows in the first stage of lactation and on green food are, nevertheless, approaching the values given by the above mentioned authors. On the contrary, minimal and maximal values exceed in summer and winter the values determined by Kronfeld in healthy cows $\left(0.046-0.864 \mathrm{mmol}^{-1}\right)$, not, however, reaching the maximal values given by this author for cows with spontaneous ketosis $\left(1.605 \mathrm{mmol} \mathrm{.1}{ }^{-1}\right)$, with abomasal disturbances $\left(1.789 \mathrm{mmol}^{-1}\right)$ or with $1-5$ days of starvation $\left(2.216 \mathrm{mmol} .1^{-1}\right)$ in any group of cows. Clinically ill cows and cows under therapy were not, however, included in our experimental sets of cows.

Taking into account the lactation phase, the NEFA values found by us in the groups I and II in the winter period are greatly approaching the mean values 
given by Parker and Blowey (1976) for these phases $-0.1348 \mathrm{mmol} .1^{-1}$ for cows six weeks and $0.0648 \mathrm{mmol} . \mathrm{1}^{-1}$ for cows six months after calving. These values are subtantially lower than those given by Dale, Vik-Mo and Fjellheim (1979) for cows in the first stage of lactation $\left(0.59 \pm 0.27 \mathrm{mmol}^{-1}\right.$ in $1.5-2$ months of lactation).

The limits of $95 \%$ probability of NEFA concentrations in the examined sets of cows were as follows:

A. With summer feed rations

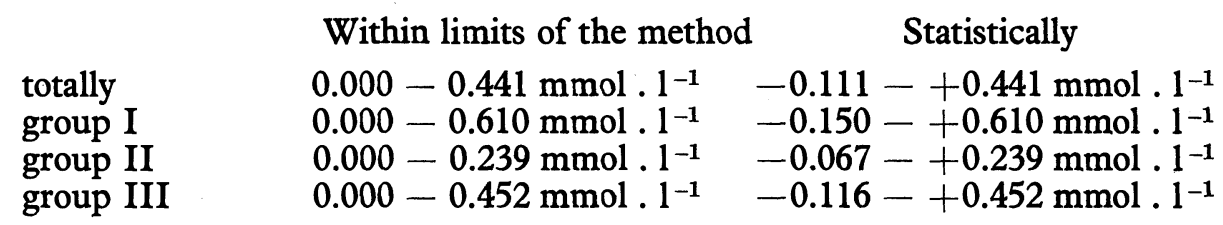

B. With winter feed rations

$\begin{array}{lll}\text { totally } & 0.000-0.437 \mathrm{mmol} \cdot 1^{-1} & -0.175-+0.437 \mathrm{mmol} \cdot 1^{-1} \\ \text { group I } & 0.000-0.467 \mathrm{mmol} \cdot 1^{-1} & -0.177-+0.467 \mathrm{mmol} \cdot 1^{-1} \\ \text { group II } & 0.000-0.205 \mathrm{mmol} \cdot 1^{-1} & -0.049-+0.205 \mathrm{mmol} .1^{-1} \\ \text { group III } & 0.000-0.431 \mathrm{mmol} .1^{-1} & -0.141-+0.431 \mathrm{mmol} .1^{-1}\end{array}$

The NEFA values in the plasma of cows in the second lactation phase were in average the lowest when summer and winter feed rations were given which correspond to the data reported by Parker and Blowey (1976) on the NEFA decrease in 9-11 weeks after calving below $0,100 \mathrm{mmol} .1^{-1}$. The variability of values was the lowest as well. If the NEFA concentration in these cows with winter feed rations is taken as a base for the preliminary determination of normal NEFA values in plasma then this value would be $0.078 \pm 0.0635 \mathrm{mmol} .1^{-1}$, i. e. the range of $0.0145-0.1415$. The precise determination of normal NEFA values would, however, need the calculation on the basis of a large number (ca. 100) of feed rations corresponding to the standard in all groups of cows.

The results have shown that the determination of NEFA in plasma in order to function as a measure of adequacy of cow nutrition is useful only in the case of sets of cows. In individual animals only extremely high values can be used as an index of energy metabolism disturbances, especially in the stage of latent disturbances. Apart from energy supplementation in feed rations the NEFA level is probably influenced also by other nutritional, hormonal and reproductive factors which complicate the interpretation of the findings from the point of view of nutrition. These factors have to be further studied. The evaluation of findings in relation to further nutritional and metabolic factors is being prepared.

We consider the negative NEFA values in the range of $95 \%$ of probability in the region of -2 SD to be a manifestation of the predominance of NEFA deposition into the fat reserves over their fat mobilization, i. e. the great energy overfeeding of animals. These values could not be found using the method of NEFA determination. 
Vliv energetických živin v letních a zimních krmných dávkách na hladinu neesterifikovaných mastných kyselin (NEMK) v krevní plazmě krav $v$ rủzných fázích laktace

Byla stanovena koncentrace NEMK v krevni plazmě 552 krav v provozních podmínkách zemědělských závodů a zjištěn stupeň krytí potřeby stravitelných dusíkatých látek (SNL) a energie (ŠJ) a jejich poměr podle ČSN 467070 . Deset krmných dávek a 178 krav spadalo do období zelených krmiv, 21 krmných dávek

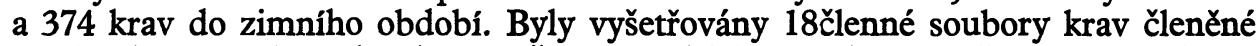
na skupiny po 6 kusech: 1) v 1 . až 2 . měsíci laktace, 2) ve 4. až 6 . měsíci laktace a 3) v 8. až 9,5. měsíci březosti, stojících nasucho.

Koncentrace NEMK jsou $\mathrm{v}$ celé populaci krav signifikantně $(P<0,01)$ vyšší při letních krmných dávkách $(0,165 \mathrm{mmol} / 1 \pm 0,138)$ s výrazným prủměrným přebytkem SNL i S̆J, než při zimních krmných dávkách $(0,131$ mmol $/ 1 \pm 0,153)$ $\mathrm{s}$ prưmèrným mírným nedostatkem SNL a mírným přebytkem ŠJ. Rozdíl letních a zimních hladin NEMK $\mathrm{v}$ celé populaci krav je způsoben především signifikantně $(P<0,001)$ vyššími hodnotami NEMK u krav v 1 . fázi laktace $(0,23 \mathrm{mmol} / 1 \pm$ $\pm 0,19 \mathrm{v}$ létě́; $0,145 \mathrm{mmol} / 1 \pm 0,161 \mathrm{v}$ zimě), které mají $\mathrm{v}$ létě prüměrně mírný nedostatek SNL a větši nedostatek ŠJ, v zimě větší nedostatek SNL a ŠJ na úrovni normy. NEMK krav v 1 . fázi laktace a krav vysokobřezích $(0,168 \mathrm{mmol} / 1 \pm 0,142$ $\mathrm{v}$ létě; $0,145 \mathrm{mmol} / 1 \pm 0,1428 \mathrm{v}$ zimě) jsou $\mathrm{v}$ létě i v zimě signifikantně $(P<0,001)$ vyšší než NEMK krav v 2 . fázi laktace $(0,086 \mathrm{mmol} / 1 \pm 0,0767$ v létě; $0,078 \mathrm{mmol} / 1$ $\pm 0,0635 \mathrm{v}$ zimě). Koncentrace NEMK krav $\mathrm{v} 1$. fázi laktace a krav vysokobřezích se signifikantně neliší ani v létě ani v zimě, ačkoli je u nich podstatný rozdíl v krytí potřeby energetických živin.

Jsou diskutovány přičiny rozdílných koncentrací NEMK $\mathrm{v}$ jednotlivých fázích reprodukčního cyklu $\mathrm{z}$ hlediska zjištěné saturace potřeby energetických živin i vlivu jiných faktorů a využitelnost stanovení NEMK plazmy jako ukazatele adekvátnosti výživy krav.

\section{Влияние энергетических питательных веществ в летних и зимних кормовых рационах на уровень неэтерифицированных жирных кислот (НЭЖК) \\ в кровяной плазме коров на разной стадии лактаџии}

Проводились определения концентрации НЭЖК в кровяной плазме 552 коров в эксплуатационных условиях сельскохозяйственных предприятий и была выявлена степень покрытия потребности в перевариваемых азотных веществах [SNL] и энергии [S̆J] и их соотношение по ЧСН 467070. Десять кормовых рационов и 178 коров приходились на период зеленых кормов, 21 кормовой рацион и 374 коров - на зимний период. Проводились исследования групп из 18 коров, разделенных на подгруппы по 6 голов: 1. на $1-2$ месяцах лактации, 2. на 4-6 месяцах лактации и 3 . на 8 и 9,5 месяцах беременности сухостойных коров.

Концентрации НЭЖК у всех коров явно $(P<0,01)$ выше при летних кормовых рационах $(0,165$ ммол/1 $\pm 0,138)$ с выразительны средним излишком азотных веществ и энергии по сравнению с зимними кормовыми рационами $(0,131$ ммол/ $1 \pm 0,153)$ со средней незначительной нехваткой азотных веществ и незначительным излишком энергии. Причина разности летних и зимних уровней НЭЖК коров кроется прежде всего в явно $(\mathrm{P}<$ $<0,001)$ более высоких величинах НЭЖК коров на 1 этапе лактации $(0,23$ 
ммол/ $1 \pm 0,19$ летом; 0,145 ммол/ $1 \pm 0,161$ зимой $)$, у которых летом наблюдается незначительная нехватка азотных веществ и бо́льшая нехватка энергии, зимой - бо́льшая нехватка азотных веществ и энергии в норме. НЭЖК коров в 1 фазе лактации и коров на высокой стадии беременности $(0,168$ ммол $1 \pm 0,142$ летом; 0,145 ммол/ $1 \pm 0,1428$ зимой $)$ летом и зимой явно $(\mathrm{P}<0,001)$ выше НЭЖК коров на 2 этапе лактации $(0,086$ ммол/1 \pm $\pm 0,0767$ летом; 0,078 ммол/ $\pm 0,0635$ зимой). Концентрации НЭЖК коров на 1 стадии лактации и коров на высокой стадии беременности существенно не отличаются ни летом, ни зимой, хотя и существует явная разница в покрытии пэтребностей в энергетических питательных веществах.

Обсуждаются причины разных концентраций НЭЖК в отдельных фазах цикла репродукции с точки зрения выявленного покрытия потребностей в энергетических питательных веществах и влияния других факторов и используемости определения НЭЖК плазмы в качестве показателя адекватности питания коров.

\section{References}

BERGMAN, E. N.: Glucose metabolism in ruminants. Proceedings Third International. Conference on Production Disease in Farm Animals. Wageningen 1976, 25-29.

BERGMAN, E. N.: Glucose metabolism in ruminants as related to hypoglycemia and ketosis. Cornell Vet. 63, 1973: $341-382$.

BERGNER, H.: Výživa zvierat. Bratislava 1971, 132 p.

BOD̆A, K.: Premena energie. In: HOLUB, A. et al.: Fyziologie hospodářských zvířat. Praha 1969, p. 552 .

BROCKMAN, R. P. - BERGMAN, E. N. - JOO, P. K. - MANNS, J. G.: Effects of glucagon and insulin on net hepatic metabolism of glucose precursors in sheep. Am. J. Physiol., 229, 1975: 1344-1350.

CAMPBELL, E. J. M. - DICKINSON, C. J. - SLATER, J. D. H.: Clinical Physiology. Oxford 1965, 605 pp.

ČN 46 7070. Potřeba živin hospodářských zvířat. 1966.

DALE, H. - VIK-MO, L. - FJELLHEIM, P.: A field survey of fat mobilisation and liver function of dairy cows during early lactation. Nordisk veter. Med. 31, 1979: 97-105.

ESPINASSE, J. - RUCKEBUSCH, Y.: Metabolic disorders in high-yield dairy cows prior to and post parturition. Proceedings of the Third International Conference on Production Disease in Farm Animals. Wageningen, September 13-16, 1976: 40-44.

FISHER, L. J. - DONELLY, P. E. - HUTTON, J. B. - DUGANZICH, D. M.: Relationship between level of feeding and certain blood metabolites in dairy cows in mid-lactation. J. agric. Sci. (Camb.), 84, 1975: 29-37.

HOLUB, A. et al.: Fyziologie hospodářských zvírat. Praha 1969, 673 p.

HOMOLKA, J.: Chemická diagnostika $\mathrm{v}$ dětském věku. (PICKO, V.: Statistické hodnocení výsledků.) Praha 1956, 508 p.

KOLB, E. - GÜRTLER, H.: Ernährungsphysiologie der landwirtschaftlichen Nutztiere. Jena $1971,957 \mathrm{p}$.

KRONFELD, P. S.: Plasma non-esterified fatty acid concentrations in dairy cow: Response to nutritional and hormonal stimuli, and significance in ketosis. Veter. Rec. 77, 1965: 40-34.

LEBEDA, M. - PŘIKRYLOVÁ, J. - BUŚ, A.: Krytí potřeby energetických živin $\mathrm{v}$ letních a zimních krmných dávkách krav podle fáze laktace v létech 1975-1979 a jeho vliv na některé metabolické ukazatele. Veterinářství 1980 - in preparation.

LUTHMAN, J. - JOHNSON, G.: The relationship between serum calcium and plasma nonesterified fatty acids in normal and hypocalcemic cows and sheep. Acta veter. Scand., 13, 1972a: $42-55$.

LUTHMAN, J. - JOHNSON, G.: Short-term hormonal effects on blood glucose and nonesterified fatty acids in female sheep. Acta veter. Scand. 13, 1972b: 112-127.

PARKER, B. N. J.: Plasma glucose and nonesterified fatty acids in relation to dietary energy intake in the dairy cow. Proceedings of the Third International Conference on Prodtuction Disease in Farm Animals. Wageningen, September 13-16, 1976: 34-36. 
PARKER, B. N. J. - BLOWEY, R. W.: Investigation into relationship of selected blood components to nutrition and fertility of the dairy cow under commercial farm conditions. Vet. Rec., 15, 1976: 394-404.

PEHRSON, B.: Studies on lipid pattern in healthy dairy cows. Acta Vet. Scand. 1971, 12, 230 to 242 .

RADLOFF, H. D. - SCHULTZ, L. H. - HOEKSRTA, W. G.: Relationship of plasma free fatty acids to other blood components in ruminants under various physiological conditions. J. Dairy Sci. 49, 1966: 179-182.

RÉMOND, B. - TOULLEC, R. - JOURNET, M.: Evolution chez la vache laitière des teneurs de différents constituans du sang à la fin de la gestation et an début de la lactation. Ann. Biol. Anim., 13, 1973: 363-380.

ROOK, J. A. F. - LINE, C.: The effect of the plane of energy nutrition of the cow on the secretion in milk of the constituents of the solids-non-fat fraction and on the concentration of certain blood-plasma constituents. Brit. J. Nutr., 15, 1961: 109-119.

STOJANOVSKÝ, 1979, cit. BOĎA, K., 1969.

SARABRIN, I. G. et al.: Ketozy. Moskva 1972, 61 p.

WRIGHT, S. - KEELE, C. A. - NEIL, E. - JEPSON, J. B.: Klinická fyziologie. Praha 1967 $680 \mathrm{p}$. 